\title{
Profil Pneumonia pada Anak di RSUD Dr. Zainoel Abidin, Studi Retrospektif
}

\author{
Nurjannah, Nora Sovira, Sidqi Anwar \\ Departemen Ilmu Kesehatan Anak Fakultas Kedokteran,Universitas Syiah Kuala RSUD Dr Zainoel \\ Abidin, Banda Aceh
}

\begin{abstract}
Latar belakang. Pneumonia merupakan proses inflamasi pada parenkim paru yang dapat terjadi pada segala usia dan merupakan salah satu penyebab kematian pada anak.

Tujuan. Mengetahui profil pneumonia pada anak yang dirawat di RSUD Dr. Zainoel Abidin, Propinsi Aceh.

Metode. Studi retrospektif, data didapatkan dari rekam medis RSUD Dr. Zainoel Abidin selama Januari 2008 sampai Desember 2009, pada anak yang dirawat dengan pneumonia

Hasil. Didapatkan $144(7,1 \%)$ anak dengan pneumonia di antara 2035 pasien rawat inap. Insidens pada tahun 2008 (77) kasus dan 2009 (67) kasus. Gambaran klinis berupa batuk (94,4\%), napas cuping hidung $(93,1 \%)$, ronki $(92,3 \%)$, demam $(76,4 \%)$ dengan suhu $38^{\circ} \mathrm{C}$, takipnu rata-rata laju napas $60 \mathrm{kali} / \mathrm{menit}$, takikardi dengan denyut nadi $146 \mathrm{kali} /$ menit disertai retraksi otot-otot dinding dada, mengi dan pilek. Leukositosis rata-rata $14.000 / \mathrm{mm}^{3}$ dan hasil foto toraks sesuai dengan pneumonia $95,8 \%$.

Kesimpulan. Angka kejadian pneumonia masih tinggi pada anak yang dirawat di bangsal anak RSUD Dr. Zainoel Abidin. Sari Pediatri 2012;13(5):324-8.
\end{abstract}

Kata kunci: anak, pneumonia, gambaran klinis, laboratorium, foto toraks

$\mathrm{P}$ neumonia merupakan proses inflamasi yang terjadi pada parenkim paru. ${ }^{1,2}$ Pada anak, pneumonia merupakan penyakit yang paling umum terjadi dan sebagai salah satu penyebab kesakitan dan kematian utama pada anak (paling banyak anak di bawah usia 5 tahun). ${ }^{1,3,4}$ Pneumonia

\footnotetext{
Alamat korespondensi:

Dr. Nurjannah Sp.A. Departemen Ilmu Kesehatan Anak RSUD Dr. Zainoel Abidin, Jl. TGK Daud Beureuh No. 108, Banda Aceh, Kota Banda Aceh Nangroe Aceh Darussalam
}

disebabkan oleh mikroorganisme, aspirasi dari cairan lambung, benda asing, hidrokarbon, bahan-bahan lipoid, dan reaksi hipersensitivitas. ${ }^{1}$

Gambaran klinis pneumonia ditandai dengan demam, takipnu, usaha napas meningkat, disertai tarikan otot-otot dinding dada, disertai napas cuping hidung. ${ }^{1}$ Pada infeksi yang berat dapat dijumpai sianosis dan gagal napas. Pada pemeriksaan fisik didapatkan ronki dan mengi. ${ }^{1,2,4,5}$ Saat ini belum ada penelitian mengenai profil pneumonia pada anak di Aceh, oleh karena itu penelitian ini dilakukan untuk mengetahui bagaimana profil tahun 2008 dan tahun 2009 . 


\section{Metode}

Penelitian retrospektif dengan mengambil data dari rekam medik. Data rekam medis selama 2 tahun (awal tahun 2008 sampai akhir tahun 2009) terdapat 2035 anak yang menjalani rawat inap di bangsal anak RSUD Dr. Zainoel Abidin dan 144 anak diantaranya menderita pneumonia, usia mulai dari 1 bulan hingga 18 tahun. Diagnosis pneumonia ditegakkan sesuai dengan kriteria WHO. Anak dengan gejala klinis batuk, kesulitan bernapas, dan laju pernapasan yang meningkat (anak $<2$ bulan; mempunyai laju napas $>60$ $\mathrm{kali} /$ menit; $2-11$ bulan laju napas $>50 \mathrm{kali} / \mathrm{menit}$; dan 13-60 bulan laju napas $>40 \mathrm{kali} / \mathrm{menit})$. Penyakit paru lainnya tidak diikutsertakan dalam penelitian.

Data yang dikumpulkan mengenai gejala klinis pneumonia adalah batuk, demam, sesak napas, laju napas meningkat, napas cuping hidung, retraksi pada dinding dada, sianosis, ronki, dan mengi. Pemeriksaan

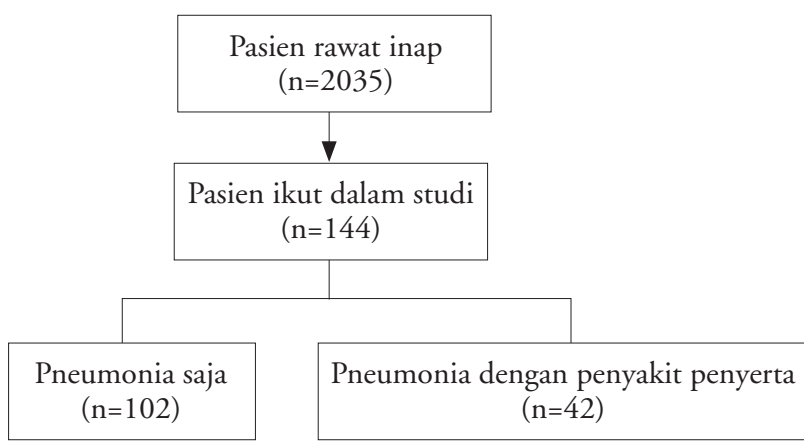

Gambar 1. Jumlah pasien penelitian penunjang berupa laboratorium dan foto radiologik dada. Penyakit lainnya yang menyertai pneumonia juga dicatat.

Data kemudian dimasukkan ke dalam program SPSS 16.0 dan dianalisis. Penelitian telah disetujui oleh Komite Etik Fakultas Kedokteran UNSYIAH, provinsi Aceh.

\section{Hasil}

Pengambilan subjek untuk kasus pneumonia selama 2 tahun tertera pada Gambar 1.

Insiden kasus pneumonia setiap bulan tertera pada Gambar 2. Insidens paling tinggi terjadi pada bulan November dan Desember.

Terdapat 144 anak dengan pneumonia, terdiri dari $86(59,7 \%)$ laki-laki dan 58 (40,3\%) perempuan dengan usia anak rata-rata 15 bulan. Kasus paling banyak terjadi pada kelompok usia $2-11$ bulan $(58,3 \%)$, dengan gizi baik 49,3\% (Tabel 1). Berdasarkan gambaran klinis, batuk merupakan gejala klinis paling banyak ditemukan yaitu $94.4 \%$ diikuti napas cuping hidung $93,1 \%$, dan ronki $92,4 \%$, kemudian demam dengan suhu rata-rata $38^{\circ} \mathrm{C}$, takipnu dengan rata-rata laju napas $60 \mathrm{kali} / \mathrm{menit}$, takikardi dengan denyut nadi rata-rata $147 \mathrm{kali} /$ menit. Data lainnya berupa retraksi otot-otot dinding dada, mengi, pilek, muntah, diare, kejang dan sianosis (Tabel 2). Lama sakit sebelum anak dirawat di rumah sakit terbanyak setelah hari ke-3 yaitu 58,3\%, diikuti hari sakit ke-5 dan kurang dari 2 hari, dengan lama rawat inap rata-rata 8 hari. (Tabel 2)

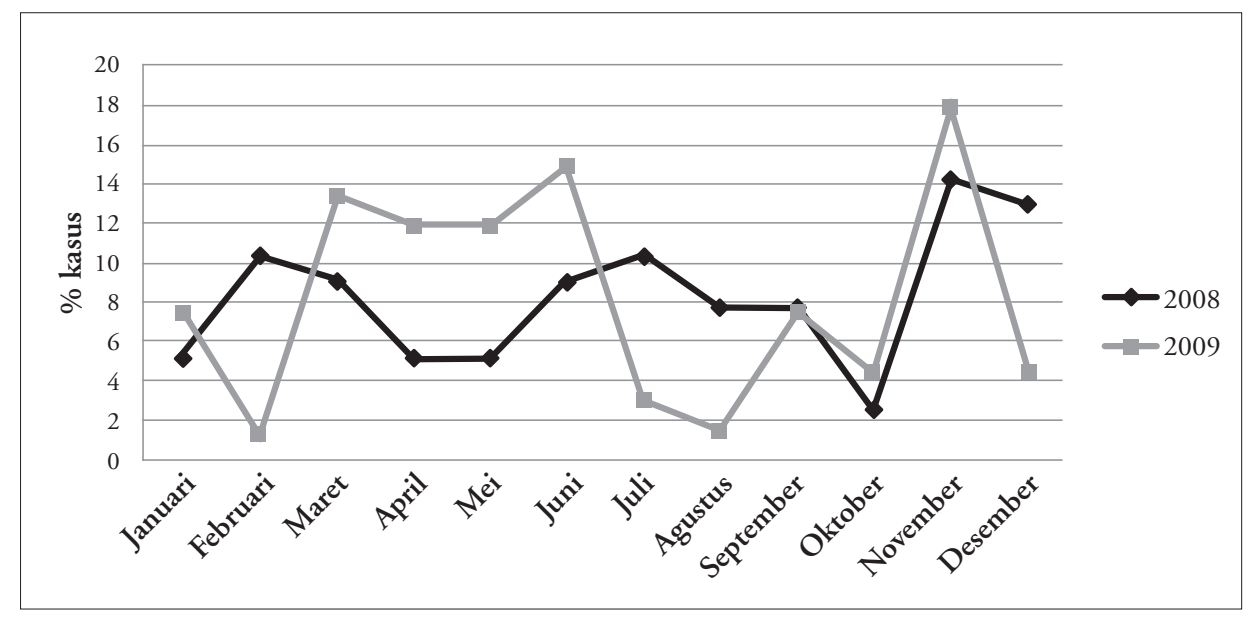

Gambar 2. Persentase kasus pneumonia selama tahun 2008 dan 2009 
Pemeriksaan laboratorium yang dilakukan adalah pemeriksaan darah perifer lengkap dan pemeriksaan foto radiologik dada. Data pemeriksaan darah perifer menunjukkan nilai leukosit sekitar $14.000 / \mathrm{mm}^{3}$ dan hasil foto torak menunjukkan gambaran pneumonia

Tabel 1. Karakteristik dasar

\begin{tabular}{lc}
\hline Variabel & \\
\hline Tahun (n,\%) & $77(53,5)$ \\
2008 & $67(46,5)$ \\
2009 & \\
Jenis kelamin (n,\%) & $86(59,7)$ \\
$\quad$ Laki-laki & $58(40,3)$ \\
$\quad$ Perempuan & $15,9(25,4)$ \\
Usia, bulan, rerata (SB) & \\
Kelompok usia, bulan, n (\%) & $14(9,7)$ \\
$\quad<2$ & $84(58,3)$ \\
$2-11$ & $36(25,1)$ \\
$12-60$ & $10(6,9)$ \\
$\quad>60$ & \\
Status gizi & $71(49,3)$ \\
Baik & $54(37,5)$ \\
Kurang & $16(11,1)$ \\
Buruk & $3(2,1)$ \\
$\quad$ Lebih & \\
\hline
\end{tabular}

Tabel 2. Manifestasi klinis pneumonia

\begin{tabular}{lc}
\hline \multicolumn{1}{c}{ Variabel } & $\mathrm{n}(\%)$ \\
\hline Batuk & $136(94,4)$ \\
Demam & $110(76,4)$ \\
Suhu, rerata (SB) & $38,1(0,8)$ \\
Takipnu, rerata (SB) & $60,2(10,5)$ \\
Takikardia, rerata (SB) & $147,2(15,7)$ \\
Napas cuping hidung & $134(93,1)$ \\
Retraksi dinding dada & $95(66)$ \\
Ronki & $133(92,4)$ \\
Mengi & $13(9)$ \\
Pilek & $31(21,5)$ \\
Muntah & $26(18,1)$ \\
Diare & $15(10,4)$ \\
Kejang & $5(3,5)$ \\
Sianosis & $14(9,7)$ \\
Hari onset penyakit & \\
$\quad$ 1-2 & $45(31,3)$ \\
3-5 & $84(58,3)$ \\
Lama rawat, hari, rerata (SB) & $15(10,4)$ \\
Kematian & $8,5(2,9)$ \\
\end{tabular}

Tabel 3. Pemeriksaan penunjang

\begin{tabular}{ll}
\hline Variabel & rerata $(\mathrm{SB})$ \\
\hline Laboratorium & \\
$\quad$ Hemoglobin & $10,9(1,4)$ \\
$\quad$ Hematokrit & $32,5(5,1)$ \\
$\quad$ Leukosit & $14,051(6231,3)$ \\
$\quad$ Trombosit & $361.638(134.159,8)$ \\
Foto radiologi dada (n,\%) & \\
$\quad$ Pneumonia & $138(95,8)$ \\
\hline
\end{tabular}

Tabel 4. Penyakit penyerta

\begin{tabular}{lc}
\hline Diagnosis & $\mathrm{n}$ \\
\hline Atelektasis & 1 \\
Tuberkulosis dan gizi buruk & 6 \\
Penyakit jantung bawaan & 8 \\
Penyakit jantung bawaan dan diare & 1 \\
Gastroenteritis & 12 \\
Morbili & 4 \\
Kejang demam & 1 \\
Gizi buruk & 2 \\
Palsi serebal dan gizi buruk & 5 \\
Palsi serebral dan diare & 2 \\
\hline
\end{tabular}

95,8\% kasus (Tabel 3). Pneumonia dapat bisa terjadi bersamaan dengan penyakit lainnya, terbanyak gastroenteritis terjadi pada 12 kasus (8,3\%) (Tabel 4).

\section{Pembahasan}

Pneumonia masih merupakan penyebab kesakitan dan kematian yang tinggi pada anak di bawah usia 5 tahun di negara-negara berkembang. ${ }^{1,6}$ Temuan kami menunjukkan insidens pneumonia yang masih tinggi baik pada tahun 2008 dan juga tahun 2009. Di antara 2035 kasus anak yang dirawat, selama 2 tahun tersebut dari 2035 kasus tersebut terdapat $144(7,1 \%)$ kasus pneumonia termasuk yang disertai dengan penyakit lain. Penelitian di Pakistan selama satu tahun didapatkan insiden pneumonia lebih tinggi yaitu 38,2\% kasus. ${ }^{7}$ Penelitian di Meksiko menunjukkan 724 kasus pneumonia yang dikonfirmasi dengan radiologi selama 16 bulan pengamatan. ${ }^{8}$ Sedangkan di RS. Toronto Kanada mendapatkan 238 kasus pneumonia selama waktu 10 tahun, serta di Gabon didapatkan 103 kasus anak dengan pneumonia. ${ }^{9,10}$ 
Usia rata-rata kasus pneumonia yang kami dapatkan adalah 15 bulan. Penelitian Tiewosh dkk ${ }^{11}$ mendapatkan usia rata-rata pneumonia adalah 11 bulan, di Gabon didapatkan usia 14 bulan, sedangkan pada penelitian di Texas didapatkan terbanyak pada usia 6 bulan hingga 2 tahun. ${ }^{12}$

Persentase pneumonia pada anak laki-laki lebih besar dibandingkan dengan anak perempuan. Laporan penelitian yang dilakukan di beberapa negara seperti Amerika dan Thailand melaporkan hal yang sama. ${ }^{13}$ Kasus pneumonia sudah banyak diteliti di berbagai negara di dunia dengan hasil yang bervariasi pada insidens, kuman penyebab, dan angka kematian. Temuan kami memperlihatkan pada kasus pneumonia lebih banyak terjadi pada bulan November dan Desember pada tahun 2008 sedangkan pada tahun 2009 lebih banyak pada bulan Juni dan November. Penelitian di Irak mendapatkan insidens tertinggi pada bulan Februari. ${ }^{13}$

Manifestasi klinis sesuai dengan kriteria WHO untuk pneumonia yaitu batuk, demam, takipnu, peningkatan usaha napas, napas cuping hidung, dan hipoksia didukung dengan pemeriksaan penunjang foto toraks. ${ }^{14}$ Batuk merupakan manifestasi klinis yang paling banyak dijumpai dalam penelitian ini, diikuti dengan napas cuping hidung, ronki, demam, takipnu, takikardia, batuk, retraksi dinding dada, mengi, dan pilek. Penelitian sebelumnya yang dilakukan di Iraq dan Gabon, menunjukkan bahwa batuk merupakan gejala paling banyak dijumpai. ${ }^{10,13,14}$ Sedangkan takipnu merupakan salah satu gejala klinis yang penting dalam menegakkan diagnosis pneumonia. Pada penelitian kami didapatkan rata-rata laju napas sekitar 60 kali/ menit. Data penelitian menyatakan bahwa takipnu pada pneumonia mempunyai nilai sensitivitas $74 \%$ dan spesifisitas $67 \%$ dibandingkan dengan foto toraks sebagai baku emas, maka dinyatakan bahwa takipnu dapat digunakan sebagai tanda klinis dalam menegakkan diagnosis pneumonia. ${ }^{15}$

Demam juga merupakan gejala yang paling sering terjadi, suhu yang tinggi pada umumnya terjadi pada infeksi yang disebabkan oleh bakteri. ${ }^{1}$ Kami mendapatkan demam pada 76,4\% kasus, kemungkinan penyebab pneumonia adalah bakteri. Diagnosis pneumonia dikonfirmasi dengan gambaran infiltrat pada hasil foto toraks anteroposterior dan lateral. ${ }^{5,16}$ Kami mendapatkan hasil pemeriksaan foto toraks sesuai gambaran pneumonia pada 95,8\% kasus. Hasil pemeriksaan darah rutin dapat menunjukkan leukositosis. Penelitian sebelumnya yang dilakukan oleh Michelow juga menemukan nilai leukosit pada kasus pneumonia yang tertinggi adalah $16.000 / \mathrm{mm}^{3}$ yang disebabkan oleh bakteri. ${ }^{12}$

Untuk menemukan kuman penyebab, sebaiknya dilakukan kultur darah. Pemeriksaan secara klinis dan radiologi juga dapat melihat apakah penyebabnya bakteri, virus atau mycoplasma, namun hal ini masih kontroversial. ${ }^{17}$ Kuman penyebab menurut usia sudah pernah diteliti dengan hasil bahwa sejak lahir hingga usia 3 minggu penyebabnya tidak spesifik, usia 3 minggu hingga 3 bulan penyebabnya adalah C.trachomatis dan Bordetella pertussis, pada anak yang lebih tua disebabkan M.pneumonia dan C.pneumoniae, untuk usia 5 sampai 15 tahun paling banyak ditemukan M.pneumoniae. ${ }^{18,19}$

Permasalahan dalam pengobatan adalah, apakah perlu diberikan antibiotik atau tidak masih sering terjadi. Kenyataannya banyak para klinisi yang mengatasi dilema ini dengan memberikan antibiotik spektrum luas. ${ }^{17}$ Tata laksana pneumonia bersifat empiris dan sering terjadi penggunaan antibiotik berlebihan. ${ }^{20}$

Lama rawat sekitar 8 hari, berhubungan dengan lama pemberian antibiotik. Pada penelitian lain yang dilakukan di Texas, didapatkan bahwa lama rawatan pneumonia lebih dari 5 hari. ${ }^{12}$ Angka kematian pada pneumonia paling sering dihubungkan dengan status gizi yang buruk. ${ }^{8}$ Pada penelitian kami gizi buruk terjadi pada 16 kasus (11\%). Angka kematian 4 kasus $(2,8 \%)$, dengan 2 kasus gizi buruk, dan 1 kasus gizi kurang.

Keterbatasan penelitian karena tidak diperoleh hasil kultur darah untuk mencari kuman penyebab pneumonia yang menjadi dasar tata laksana selanjutnya dan sebaiknya dilakukan penelitian lanjutan untuk hal ini. Disimpulkan bahwa telah didapatkan gambaran profil anak dengan pneumonia yang dirawat di bangsal anak RSUD Dr. Zainoel Abidin NAD dalam waktu dua tahun. Kejadian pneumonia masih tinggi $(7,1 \%)$ diantara pasien rawat inap. Batuk, napas cuping hidung, ronki, demam, takipnu merupakan gejala klinis yang sering ditemukan. Kematian didapatkan pada 2,8\% kasus.

\section{Daftar pustaka}

1. Sectish TC, Prober CG. pneumonia. Dalam: Behrman RE, Kliegman RM, Jenson HB, penyunting. Nelson textbook of pediatrics. Edisi ke-18. Philadelphia: WB Saunders 2008; h. 1795-99. 
2. Said M .Pneumonia. Dalam: Rahajoe NN, Supriyatno B, Setyanto DB, penyunting. Buku Ajar Respirologi Anak. Edisi ke-1. Jakarta: Badan Penerbit Ikatan Dokter Anak Indonesia;2008.h. $350-354$

3. Scott JAG, Brooks WA, Peiris JSM, Holtzman D, Mulholland EK. Pneumonia research to reduce childhood mortality in the developing world. J Clin Invest 2008;118:1291-300.

4. Stein RT. Paulo JC, Marostika. Community-acquired bacterial pneumonia. Dalam: Chernick V, Boat TF, Wilmot RW. Bush A, penyunting. Kendig's Disorders of the respiratory tract in children. Edisi ke-7. Philadelphia:WB Saunders;2006.h.441-3

5. Gross I. Pneumonia. Dalam: McMillan JA. Deangelis CD, Feigin RD, Warshaw JB, Oski FA, Warshaw JB. penyunting. Oski's Pediatric: Principles and Practice, Edisi ke-3. Philadelphia: Lippincott Williams \& Wilkins; 1999. h.64-7

6. World Health Organization. pneumonia the forgotten killer of children. Diakses pada tanggal: 16 Januari 2011. Diunduh dari: http://www.unicef.org/publications/files/ Pneumonia_The_Forgotten_Killer_of_Children.pdf

7. Hazir T. Assessment and management of children aged 1 - 59 months presenting with wheeze, fast breathing, and/or lower chest indrawing; a result of a muticentre descriptive study in Pakistan. Arch Dis Child 2004; 89:1049-54

8. Andrade AL, Silva SA, Martelli CMT, Oliveira RM, Neto OL, Junior JBS, dkk. Population-based surveillance of pediatric pneumonia: use of spatial analysis in an urban area of Central Brazil. Cad Saude Publica 2004; 20:411-21

9. Owayed AF, Campbell DM,Wang EEL. Underlying causes of recurrent pneumonia in children. Arch Pediatr Adolesc Med 2000;154:190-4
10. Lassmann B, Poetschke M, Ninteretse B, Issifou S. Winkler S, Kremsner PG, dkk. Community-acquired pneumonia in children in Lambarene, Gabon. Am J Trop Med Hyg 2008;79: 109-14

11. Tiewosh K, Lodha R, Pandey RM, Broor S, Kalaivani M, Kabra SK. Factors determining the outcome of children hospitalized with severe pneumonia. BMC pediatrics 2009; 9:15

12. Michelow IC. Epidemiology and clinical characteristics of community-acquired pneumonia in hospitalized children. Pediatrics 2004;113: 701-7

13. Al-Ghizawi G.J, Al-Sulami A.A, Al-Taher S.S. Profile of community - and hospital - acquired pneumonia cases admitted to Basra General Hospital, Iraq. Eastern Mediterranean Hlth J 2007; 13:230-42.

14. Gessman LM, Rappaport DI. Approach to communityacquired pneumonia in children. Hosp Physician 2009;1-5

15. Palafox M, Guiscafre H, Reyes $\mathrm{H}$, Munoz O, Martinez $H$. Diagnostic value of tachypnoe in pneumonia defined radiologically. Arch Dis Child 2000; 82:41-5

16. Sondheimer JM. Respiratory tract. Dalam: Sondheimer, penyunting. Current essential pediatrics. New York : McGraw Hill companies Inc; 2008. h.1-20

17. John D, Nelson. Community-acquired pneumonia in children: guidelines treatment. Pediatr Infect Dis J 2000; 19:251-3

18. McIntosh K. Community-acquired pneumonia in children. N Engl J Med 2004;346:429-37

19. Ostapchuk M, Roberts DM, Haddy R. Communityacquired pneumonia in infants and children. Am Fam Physician 2004;70:899-908.

20. Sinaniotis CA, Sinaniotis AC. Community-acquired pneumonia in children. Curr Opin Pulm Med 2005; 1 : 218-25. 